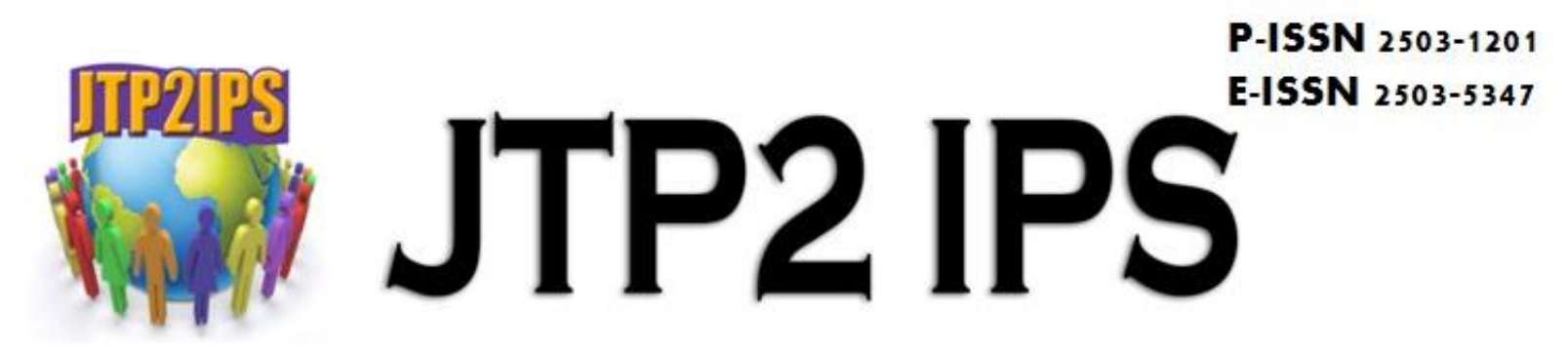

\title{
PENGARUH PEMBELAJARAN IPS BERBASIS PROYEK TERHADAP PERSEPSI KONSUMSI BERKARAKTER MAHASISWA S1 PENDIDIKAN IPS UNIVERSITAS NEGERI MALANG
}

\author{
Khofifatu Rohmah Adi $^{1}$, Fatiya Rosyida ${ }^{2}$, Neni Wahyuningtyas ${ }^{3}$
}

\begin{abstract}
Abstrak
Penelitian ini bertujuan untuk mengetahui pengaruh pembelajaran IPS berbasis proyek terhadap persepsi konsumsi berkarakter mahasiswa. Persepsi konsumsi berkarakter pada penelitian ini difokuskan pada konsumsi berwawasan lingkungan karena ditemukan fakta bahwa mahasiswa kurang peduli terhadap lingkungannya, terutama kebersihan kelas. Jenis penelitian yang digunakan termasuk quasi eksperimen, yang bertujuan menilai pengaruh suatu tindakan pembelajaran terhadap persepsi mahasiswa sebelum dan sesudah perlakuan. Subjek penelitian adalah mahasiswa Prodi S1 IPS angkatan 2015 yang mengikuti mata kuliah pengantar ekonomi. Instrumen yang digunakan untuk mengukur persepsi konsumsi berwawasan lingkungan menggunakan angket dengan skala likert. Berdasarkan uji homogenitas kemampuan kognitif mahasiswa diperoleh kesimpulan memiliki karakter yang homogen sehingga penentuan kelas eksperimen dan kontrol dilakukan secara random. Penelitian ini dianalisa program SPSS 22.0 for windows menggunakan Independent Sample T-Test. Hasil analisa menunjukkan terjadi perbedaan signifikan antara kelas kontrol dengan kelas eksperimen. Oleh sebab itu, dapat disimpulkan bahwa penerapan pembelajaran IPS berbasis proyek berpengaruh terhadap persepsi konsumsi berkarakter. Dalam pembelajaran berbasis proyek memungkinkan mahasiswa berusaha mengkonstruk sendiri pengetahuannya dan terlibat aktif dalam mencari informasi sehingga diharapkan mahasiswa mampu menghubungkan teori yang diperoleh dengan realita yang ada di lingkungan.
\end{abstract}

Kata kunci: Pembelajaran Berbasis Proyek, Persepsi Konsumsi Berkarakter

\begin{abstract}
This study aims to determine the effect of the project-based learning social studies consumer perceptions of student character. Consumer perception of the character of this research is focused on the consumption of environmentally sound because it was found that the students are less concerned about the environment, especially the cleanliness class. This type of research including quasi experimental, aimed at assessing the effect of an action learning on students' perceptions before and after treatment. Subjects were students of 2015 batch S1 IPS which follows the introductory economics course. The instrument used to measure the consumption of environmentally sound perception using a questionnaire with Likert scale. Based on the homogeneity test the cognitive abilities of students conclusion has a homogeneous character and definitive experimental group and the control is done randomly. This study analyzed SPSS 22.0 for Windows using independent sample T-test. Results of the analysis showed that there were significant differences between the control and experimental class class. Therefore, it can be concluded that the application of project-based learning IPS effect on consumer perceptions of character. In project-based learning allows students trying to construct their own knowledge and actively involved in seeking information so it is expected that students are able to connect theory gained with the existing reality in the environment.
\end{abstract}

Keywords: Project Based Learning, Perception Character consumption

\footnotetext{
${ }^{1}$ Prodi Pendidikan IPS Fakultas Ilmu Sosial - Universitas Negeri Malang, khofifatu.rohmah.fis@um.ac.id

${ }^{2}$ Jurusan Geografi Fakultas Ilmu Sosial - Universitas Negeri Malang, fatiya.rosyida.fis@um.ac.id

${ }^{3}$ Prodi Pendidikan IPS Fakultas Ilmu Sosial - Universitas Negeri Malang, neni.wahyuningtyas.fis@um.ac.id
} 


\section{PENDAHULUAN}

Peradaban manusia telah berkembang dan berlangsung ribuan tahun sampai sekarang yang dikenal dengan era globalisasi. Globalisasi menciptakan homogenisasi yang berarti manusia memiliki budaya konsumtif yang sama. Proses homogenisasi tersebut disebut sebagai proses konvergensi di mana peradaban konsumtif yang bersumber dari kapitalistik telah berkembang sangat cepat. Hal ini dibuktikan dengan adanya produksi dan konsumsi yang secara cepat berlangsung menciptakan proses eksploitasi sumber daya alam untuk dikonsumsi.

Konsumsi sebenarnya bukan hanya sekedar kegiatan menghabiskan barang dan jasa saja. Akan tetapi kegiatan ini juga termasuk kegiatan yang mengawali dan yang menyusuli tindakan ini, termasuk dampak yang diakibatkan setelahnya. Namun sayangnya masih banyak masyarakat yang belum sadar akan konsep ini. Pada umumnya mereka berasumsi bahwa konsumsi hanyalah sekedar menghabiskan sumber daya yang ada. Hal tersebut nampak pada perilaku manusia yang cenderung serakah pada lingkungan. Dampak yang dapat kita rasakan diantaranya adalah perubahan cuaca secara global, suhu udara meninggi, kabut asap yang terjadi di Riau belakangan ini, banjir ketika musim penghujan datang dan lain sebagainya. Oleh sebab itulah diperlukan adanya pembaharuan untuk menyadarkan mereka supaya memahami konsep sebenarnya dari konsumsi atau paling tidak mengurangi dampak dari kegiatan konsumsi yang merusak lingkungan.

Upaya untuk mengurangi dampak dari kegiatan konsumsi yang merusak lingkungan, salah satunya dengan pendidikan. UndangUndang Sistem Pendidikan Nasi-onal No 20 tahun 2003 (Hanafiah, 2012:20) mengamanatkan bahwa:

\footnotetext{
"Pendidikan sebagai usaha sadar dan terencana untuk mewujudkan suasana belajar dan proses pembelajaran agar peserta didik secara aktif mengembangkan potensi dirinya untuk memiliki kekuatan spiritual keagamaan, pengendalian diri, kepribadian, kecerdasan dan akhlak mulia, serta ketrampilan yang diperlukan dirinya, masyarakat, bangsa dan Negara".
}

Hal ini berarti bahwa pendidikan bukan hanya sekedar mengubah aspek kognitif saja, atau hanya sekedar membuat anak dari tidak tahu menjadi tahu. Akan tetapi pendidikan memiliki kewajiban untuk memberikan keterampilan juga menanamkan akhlak mulia atau karakter. Karakter yang dapat ditanamkan pada peserta didik terkait dengan kegiatan konsumsi adalah sikap konsumsi berwawasan lingkungan. Selain itu pembelajaran juga dapat membuat seseorang memiliki cara pandang yang berbeda dalam menyikapi sesuatu. Dalam hal ini cara pandang yang dimaksud yaitu perilaku konsumsi. Salah satu model pembelajaran yang dinilai sangat efektif untuk mengubah persepsi mahasiswa tentang kegiatan konsumsi adalah Project Based Learning.

Esche (dalam Rais, 2014) menjelaskan bahwa penelitian berbasis proyek pertama kali dilakukan pada mahasiswa tingkat tiga Steven Institute of Technology (SIT) Hoboken USA suatu sekolah tinggi bidang teknik mesin. Penelitian itu menunjukkan bahwa pada mata kuliah mekanika teknik, mekanisme mesin dan dinamika mesin menunjukkan bahwa pembelajaran berbasis proyek dapat meningkatkan kemampuan berpikir tingkat tinggi, keterampilan berpikir kritis, pemahaman mendalam terhadap masalah dan meningkatkan relasi kelompok belajar sebagai ciri belajar autentik.

Model pembelajaran berbasis proyek melalui enam tahapan pembelajaran yaitu: (1) start with the essential question, (2) design a plan for the project, (3) create a schedule (4) monitor the student and the progress of the project (5) asses the outcome, (6) evaluate the experiences (The George Lucas Educational, dalam Amanda, dkk: 2014). Metode pembelajaran ini sangat cocok diterapkan untuk tema yang membutuhkan tingkat pemahaman yang lebih tinggi dari sekedar ranah kognitif saja. Oleh sebab itu, penelitian ini membahas topik tentang pengaruh pembelajaran berbasis proyek terhadap persepsi konsumsi berkarakter mahasiswa S1 Pendidikan IPS Universitas Negeri Malang.

\section{METODE}

Penelitian ini menggunakan rancangan penelitian eksperimen semu (quasi) non equivalent control group design yang bertujuan untuk menilai pengaruh suatu tindakan pembelajaran terhadap persepsi mahasiswa sebelum dan sesudah perlakuan. Secara prosedural rancangan penelitian ini mengikuti pola seperti yang ditujukkan dalam tabel berikut ini: 
Tabel 1. Eksperimen Semu (Quasi) Non Equivalent Control Group Design

\begin{tabular}{llll}
\hline Kelompok 1 & O1 & X1 & O2 \\
\hline Kelompok 2 & O1 & X2 & O2 \\
\hline
\end{tabular}

Sumber: Amanda, dkk (2014)

Keterangan:

O1 : Pretes

$\mathrm{O} 2$ : Post test

$\mathrm{X} 1$ : pembelajaran berbasis proyek

$\mathrm{X} 2$ : pembelajaran konvensional

Populasi dalam penelitian ini adalah seluruh mahasiswa Program Studi S1 Pendidikan IPS Universitas Negeri Malang. Sampel dalam penelitian ini adalah mahasiswa Program Studi S1 Pendidikan IPS angkatan 2015 offering A sebagai kelas eksperimen dan mahasiswa angkatan tahun 2015 offering B sebagai kelas kontrol. Jumlah mahasiswa offering A sebanyak 36 orang dan offering B sebanyak 36 orang. Variabel bebas dalam penelitian ini adalah pembelajaran berbasis proyek dan pembelajaran konvensional. Variabel terikat adalah persepsi konsumsi berkarakter. Instrumen penelitian untuk mengumpulkan data persepsi konsumsi berkarakter dalam penelitian ini menggunakan angket dengan skala likert.

Data penelitian ini dikumpulkan pada semester gasal tahun ajaran 2015/2016. Data penelitian ini berupa data kuantitatif yang berupa skor penguasaan konsep ekonomi mikro dan skor persepsi konsumsi berkarakter. Data hasil penelitian ini menyangkut pembelajaran berbasis proyek pada materi perilaku konsumen dan pengaruhnya terhadap persepsi konsumsi berkarakter. Analisis data dilakukan dengan program SPSS 22.0 for windows menggunakan Independent Sample T-Test. Sebelum uji hipotesis dilakukan, terlebih dahulu dilakukan uji asumsi dasar sebagai prasyarat melakukan uji hipotesis berupa uji normalitas dan uji homogenitas. Uji nor-malitas menggunakan ShapiroWilk Test dan homogenitas menggunakan Levene Test. Pengujian statistik penelitian ini dilakukan pada taraf signifikansi 5\%.

\section{HASIL}

Sebelum dilakukan uji hipotesis, terlebih dahulu dilakukan uji asumsi dasar sebagai prasyarat melakukan uji hipotesis. Tujuan dari dilakukannya uji asumsi dasar adalah untuk memberikan kepastian bahwa model persamaan yang didapatkan memiliki ketepatan dalam estimasi, tidak bias dan konsisten. Uji asumsi yang digunakan dalam penelitian ini berupa uji normalitas dan homogenitas. Berdasarkan uji prasyarat dapat disimpulkan bahwa data nilai dan persepsi baik kelas kontrol maupun kelas eksperimen menunjukkan hasil data terdistribusi normal dan memiliki varians yang sama. Hasil uji asumsi dasar tersebut dapat dilihat pada tabel berikut ini:

Hasil uji hipotesis pengaruh pembelajaran berbasis proyek terhadap persepsi konsumsi berkarakter memperoleh nilai sig. 0,001. Dari uji Independent Sample T-Test dengan program SPSS, diperoleh kesimpulan bahwa ada pengaruh pembelajaran berbasis proyek terhadap persepsi konsumsi berkarakter. Selain itu, dilakukan pengujian terhadap nilai ekonomi antara kelas kontrol dengan kelas eksperimen. Hasil pengujian tersebut memperoleh nilai sig. 0,002 . Hal tersebut menunjukkan bahwa terdapat pengaruh pembelajaran berbasis proyek terhadap peningkatan nilai mahasiswa.

Tabel 2. Uji Asumsi Dasar

\begin{tabular}{|c|c|c|c|}
\hline $\begin{array}{l}\text { Uji Asumsi } \\
\text { Dasar }\end{array}$ & $\begin{array}{c}\text { Uji yang } \\
\text { Digunakan }\end{array}$ & Hasil & Kesimpulan \\
\hline $\begin{array}{l}\text { Uji } \\
\text { Normalitas }\end{array}$ & $\begin{array}{l}\text { Shapiro- } \\
\text { Wilk }\end{array}$ & $\begin{array}{l}\text { Sig. Nilai Kelas Kontrol }=0,162 \\
\text { Sig. Nilai Kelas Eksperimen }=0,090 \\
\text { Sig. Persepsi Konsumsi Berkarakter Kelas Kontrol = 0,439 } \\
\text { Sig. Persepsi Konsumsi Berkarakter Kelas Eksperimen = } \\
0,217\end{array}$ & $\begin{array}{l}\text { Data terdistribusi } \\
\text { normal }\end{array}$ \\
\hline $\begin{array}{l}\text { Uji } \\
\text { Homogenitas }\end{array}$ & Levene Test & $\begin{array}{l}\text { Sig. Nilai Kelas Kontrol dan Eksperimen }=0,695 \\
\text { Sig. Persepsi Konsumsi Berkarakter Kelas Kontrol dan } \\
\text { Eksperimen }=0,545\end{array}$ & Data homogen \\
\hline
\end{tabular}

Sumber: Hasil Pengolahan Data Oleh Peneliti 


\section{PEMBAHASAN}

Perubahan persepsi konsumsi maha-siswa tersebut terjadi karena pembelajaran berbasis proyek memungkinkan mahasiswa mengkonstruksi sendiri pengetahuannya dan terlibat aktif dalam mencari informasi. Hal tersebut menyebabkan mereka mampu memecahkan masalah dengan cara menghubungkan teori yang diperoleh dengan realita yang ada di lingkungannya. Hasil ini senada dengan penelitian Amanda, dkk (2014) yang menyatakan bahwa pembelajaran berbasis proyek memberikan kesempatan siswa untuk menjalani pemecahan masalah dengan menggunakan metode inkuiri ilmiah secara utuh. Sejalan dengan Amanda, dkk (2014), Mahanal (2009) juga mengemukakan temuan yang hampir sama. Ia berpendapat bahwa pembelajaran berbasis proyek melibatkan pebelajar dalam melakukan investigasi pemecahan masalah, dan kegiatan tugas bermakna yang lain, memberi kesempatan siswa bekerja secara otonom untuk mengkonstruk pengetahuan mereka sendiri dan mengkulminasikannya dalam produk nyata

Mahasiswa dapat memahami materi melalui pengalaman langsung sehingga mereka dapat menghubungkan antara konsep dan permasasalahan riil dalam kehidupan sehari-hari. Pengetahuan yang diperoleh melalui Pedidikan dapat mempengaruhi persepsi seseorang. Hal ini karena pendidikan mempengaruhi pola berpikir secara rasional sehingga membuka wawasan dan memperluas cara pandang hidup (Kutanegara, 2014). Persepsi yang salah pada akhirnya akan mempengaruhi bagai-mana seseorang bersikap dan berperilaku.

Sikap konsumsi berwawasan lingkungan berawal dari persepsi konsumen terhadap perilaku berwawasan lingkungan. Jika persepsi yang dimiliki positif maka sikap yang ditunjukkan juga positif. Hal ini sesuai dengan penelitian yang dilakukan oleh Isyanto, dkk (2012), yang menyatakan bahwa persepsi yang dimiliki seseorang akan mempengaruhi sikap. Kondisi ini terjadi karena persepsi merupakan proses individu dalam memilih, mengorganisasikan, dan menafsirkan, masukan informasi untuk menciptakan gambaran yang bermakna. Gambaran bermakna tersebut akan menciptakan keyakinan seseorang terhadap suatu hal sehingga berpengaruh terhadap sikap yang ditunjukkan. Sejalan dengan Isyanto, dkk
(2012), Ajzen (dalam Kutanegara, 2014) menyatakan bahwa pengetahuan menjadi dasar pembentukan keyakinan serta keyakinan menjadi bahan pertimbangan untuk menentukan sikap.

\section{PENUTUP}

Penerapan pembelajaran IPS berbasis proyek berpengaruh terhadap persepsi konsumsi berkarakter. Pembelajaran berbasis proyek memungkinkan mahasiswa mengkonstruksi sendiri pengetahuannya dan terlibat aktif dalam mencari informasi sehingga mahasiswa mampu memecahkan masalah dengan cara menghubungkan teori yang diperoleh dengan realita yang ada dilingkungannya.

Pembelajaran berbasis proyek cocok digunakan untuk materi yang membutuhkan pemahaman tingkat tinggi.

\section{DAFTAR PUSTAKA}

[1] Amanda, dkk. 2014. Pengaruh model pembelajaran berbasis proyek terhadap hasil belajar IPA ditinjau self efficacy Siswa. Ejournal Program Pascasarjana Universitas Pendidikan Ganesha Program Studi IPA. Volume 4 Tahun 2014.

[2] Djajadiningrat, Surna Tjahja. dkk. 2014. Green Economy. Bandung: Rekayasa sains Bandung.

[3] Hamid, Edi Suwandi. 2003. Asumsi Homo Ekonomikus dan Manusia Rasional Dipertanyakan. Jogjakarta: PUSTEP UGM. http://www.ekonomikerakyatan.ugm.ac.id/My $\% 20 \mathrm{Web} / \mathrm{sembul05} 4 . \mathrm{htm}$.

[4] Hanafiah, Nanang. 2012. Konsep Strategi Pembelajaran. Bandung: PT Refika Aditama.

[5] Isyanto, Puji. Dkk. 2012. Kajian Persepsi dan Perilaku Pembelian Konsumen pada Aflamart dan Indomart di Kecamatan Teluk Jambe Timur. Majalan Ilmiah UNSIKA Karawang, ISSN 1412-86676 Vol. 10 No. 21 Ed. Desember 2011-Februari 2012

[6] Kutanegara, Pande Made. 2014. Membangun Masyarakat Indonesia Peduli Lingkungan. Jogjakarta: Gadjah mada University Press.

[7] Mahanal, S. \& Wibowo , A.L. 2009. Penerapan Pembelajaran Lingkungan Hidup Berbasis Proyek untuk Memberdayakan Kemampuan Berpikir Kritis, Penguasaan Konsep, dan Sikap Siswa (Studi di SMAN 9 Malang). Makalah disajikan dalam seminar nasional Pendidikan Lingkungan Hidup dan Interkonferensi BKPSL. Universitas Negeri Malang. 
Vol.1 No.1 April 2016

P ISSN 2503 - 1201 \& E ISSN 2503 - 5347

[8] Rais, Muh. 2014. Pengembangan "Proyek" dalam Project Based Learning: Suatu Upaya Memahami, Mengembangkan, dan Menerapkan Pendekatan Scientific Learning Implementasi Kurikulum 2013 dalam Pendidikan Vokasional. Prosiding Konvensi Nasional Asosiasi Pendidikan Teknologi dan Kejuruan (APTEKINDO) ke 7 FPTK UPI, Bandung 13-14 November 2014. 